\title{
SUPERVISI AKADEMIK UNTUK MENIGKATKAN KOMPETENSI GURU DI SD LABORATORIUM UKSW
}

\author{
Suhandi Astuti \\ Suhandi.astuti70@gmail.com \\ Manajemen Pendidikan - FKIP - UKSW
}

\begin{abstract}
Academic Supervision To Improve Teachers Competence In Sd Laboratorium Uksw
\end{abstract}

Identification conducted by the principle of SD Laboratory UKSW showed that the teachers were still not competent in doing learning assessment administration well. To solve these problems, the principal conducted academic supervision. The essence of the academic supervision is to help teachers develop professional capabilities. This was also done by the principle of SD Laboratory UKSW in solving problems related to the administration assessment of learning where there were some teachers in SD Laboratory UKSW not yet competent in preparing the learning assessment administration well. Supervision technique conducted by discussion. The result of supervision performed by principle of SD Laboratory UKSW showed an increasement. At the initial conditions the average level of competence of learning assessment administration preparation was 63.5 (ideal score of 100). After given the action, the average of competence of learning assessment administration preparation was increased to 89.6. The data showed that the competence of learning assessment administration preparation has increased $26.2 \%$.

Keywords: Academic Supervision, Teachers Competence

\section{PENDAHULUAN}

Guru mempunyai peran yang sangat penting dalam proses pembelajaran. Apabila guru bekerja secara profesional bukanlah sesuatu yang mustahil jika sebuah sekolah dapat menghasilkan siswa yang unggul. Sebaliknya, jika sumber daya manusia dalam hal ini guru di sebuah sekolah tidak dikelola dengan baik, maka output siswa di sekolah tersebut pun juga akan rendah. Dengan kata lain, ada sebuah korelasi positif antara sumber daya manusia (guru) dengan kualitas siswa di sekolah, dimana sumber daya manusia tersebut membutuhkan manajemen yang baik untuk mencapai kualitas siswa yang baik. 
Menurut Marwansyah (2010: 4) Manajemen sumber daya manusia adalah pendayagunaan sumber daya manusia dalam organisasi yang dilakukan melalui fungsi-fungsi perencanaan sumber daya manusia, rekruitmen dan seleksi, pengembangan sumber daya manusia, perencanaan dan pengembangan karir, pemberian kompensasi dan kesejahteraan, keselamatan dan kesehatan kerja dan hubungan industrial.

Sedangkan menurut Bangun (2012: 6), manajemen sumber daya manusia dapat didefinisikan sebagai suatu proses perencanaan, pengorganisasian, penyusunan staf, pergerakan, dan pengawasan terhadap pengadaan, pengembangan, pemberian kompensasi, pengintegrasian, pemeliharaan, dan pemisahan tenaga kerja untuk mencapai tujuan organisasi. Masih menurut Bangun (2012: 6) orang yang melakukan aktivitas tersebut adalah manajer sumber daya manusia, yaitu seorang kepala sekolah.

Adapun mengenai kompetensi guru,Undang-UndangNomor 14 Tahun 2005 tentang Guru dan Dosen mengemukakan bahwa seorang guru adalah pendidik professional dengan tugas utama mendidik, mengajar, membimbing, mengarahkan, melatih, menilai, dan mengevaluasi peserta didik pada jalur pendidikan formal, pendidikan dasar, dan pendidikan menengah.

Berkaitan denganisi UU tentang guru dan dosen di atas, terutama tentang tugas penilaian, Permendiknas No. 16 Tahun2007 menyebutkan kompetensi guru SD/MI antara lain: 1) memahami prinsip-prinsip penilaian dan evaluasi proses dan hasil belajar sesuai dengan karakteristik lima mata pelajaran SD/MI; 2) menentukan aspek-aspek proses dan hasil belajar yang penting untuk dinilai dan dievaluasi sesuai dengan karakteristik lima mata pelajaran SD/MI; 3) menentukan prosedur penilaian dan evaluasi proses dan hasil belajar; 4) mengembangkan instrumen penilaian dan evaluasi proses dan hasil belajar; 5) mengadministrasikan penilaian proses dan hasil belajar secara berkesinambungan dengan mengunakan berbagai instrumen; 6) menganalisis hasil penilaian proses dan hasil belajar untuk berbagai tujuan; 7) melakukan evaluasi proses dan hasil belajar.

Namun pada kenyataannya, identifikasi masalah supervisi tentang pengadministrasian penilaian proses dan hasil yang dilakukan oleh kepala SD Laboratorium UKSW menunjukkan temuan bahwa garu masih belum kompeten dalam menyusun dan melaksanakan administrasi penilaian pembelajaran dengan baik. Hal ini ditunjukkan oleh fenomena berikut: 1) Ada 3 guru (23\%) yang berada pada skor kurang dari 51-60\% atau kategori kurang. Guru belum melaksanakan penilaian afektif, belum melaksanakan tugas secara terstruktur, belum melaksanakan program dan pelaksanaan remidial serta belum melakukan analisis hasil ulangan; 2) Ada 5 guru (38,5\%) yang berada pada skor $61-70 \%$ atau kategori cukup. menunjukkan guru belum membuat program dan pelaksanaan remidial, 
belum melakukan analisis hasil ulangan serta belum membuat instrumen tes dan bank soal; 3) Ada 5 guru $(38,5 \%)$ yang berada pada skor $71-85 \%$ atau kategori Baik.

Berdasarkan kondisi tersebut diatas kepala sekolah SD Laboratorium UKSW sebagai manajer sumber daya manusia melakukan Supervisi Akademik yang bertujuan untuk meningkatkan kompetensi guru dalam menyusun dan mengadministrasikan penilaian pembelajaran. Hal ini senada dengan pendapat Marwansyah (2010: 4) yang menyatakan bahwa tujuan manajemen sumber daya manusia melalui supervisi akademik adalah supaya terbangun sumber daya manusia profesional yang memiliki karakteristik beraklak mulia, kompeten dan termotivasi.

Berpijak pada latar belakang seperti di atas itulah, maka permasalahan yang akan dipecahkan dalam tulisan ini adalah berkaitan dengan bagaimana pelaksanaan Supervisi Akademik oleh kepala sekolah SD Laboratorium Kristen Satya Wacana, serta apa kendala Supervisi Akademik di SD Laboratorium Kristen Satya Wacana dan bagaimana cara mengatasinya. Sedangkan tujuan penulisan ini adalah untuk mengetahui pelaksanaan Supervisi Akademik oleh kepala sekolah SD Kristen Satya Wacana, serta mengetahui kendala Supervisi Akademik di SD Kristen Satya Wacana dan cara mengatasinya.

Manfaat penulisan ini secara teoretik adalah dapat bermanfaat bagi berkembangnya praktik supervisi di sekolah. Pelaksanaan supervisi yang tepat dapat membantu pembentukan profesionalisme guru sehingga akan mencapai tujuan pembelajaran dan selanjutnya dapat meningkatkan mutu pendidikan. Secara praktik, mafaat bagi guru adalah dapat digunakan untuk meningkatkan kemampuannya dalam proses pembelajaran yang selanjutnya dapat menunjang profesionalisme guru. Bagi kepala sekolah, dapat digunakan sebagai masukan untuk bahan pembinaan guru dalam rangka meningkatkan kompetensi guru secara berkelanjutan.

\section{KAJIAN PUSTAKA}

\section{Pengertian dan Tujuan Supervisi Pendidikan}

Piet A. Sahertian (2010: 19) berpendapat bahwa supervisi merupakan sebuah upaya pemberian layanan kepada guru-guru baik secara individual maupun secara kelompok, dengan tujuan memperbaiki pengajaran, termasuk menstimulasi, menyeleksi pertumbuhan jabatan dan perkembangan guru-guru serta merevisi tujuan-tujuan pendidikan, bahan pengajaran dan metode serta evaluasi pengajaran. Adapun yang dimaksud dengan supervisor adalah orang yang berperan dalam memberi bantuan kepada guru-guru dengan cara menstimulir guru-guru untuk mempertahankan suasana belajar mengajar yang lebih baik. Di sisi lain, Ngalim 
Purwanto (2014:76) mendefinisikan supervisi sebagai suatu aktivitas pembinaan yang direncanakan untuk membantu para guru dan pegawai sekolah lainnya dalam melakukan pekerjaan secara efektif. Supervisi diartikan sebagai bantuan yang berupa dorongan, bimbingan, dan kesempatan bagi pertumbuhan keahlian dan kecakapan guru-guru yang diberikan oleh pemimpin sekolah.

Berdasarkan pendapat yang telah dikemukakan diatas supervisi memiliki makna pemberian layanan dan bantuan untuk meningkatkan kualitas guru dalam proses pembelajaran dengan tujuan untuk meningkatkan kualitas belajar siswa yang dimulai dari perencanaan pembelajaran, pelaksanaan kegiatan pembelajaran, mengevaluasi pembelajaran sampai melakukan refleksi. Selain untuk meningkatkan kualitas pembelajaran supervisi bertujuan untuk pengembangan sumber daya guru.

Selanjutnya, Suharsimi (2004: 4) mengartikan supervisi akademik sebagai suatu kegiatan yang dilakukan oleh pengawas dan kepala sekolah untuk mengawasi serta meninjau pekerjaan guru.

Menurut Sudjana Nana dkk (2011: 19), Supervisi akademik merupakan fungsi pengawas berkenaan dengan aspek pelaksanaan tugas pembinaan, pemantauan, penilaian dan pelatihan professional guru dalam (1) merencanakan pembelajaran; (2) melaksanakan pembelajaran; (3) menilai hasil pembelajaran; (4) membimbing dan melatih peserta didik, dan(5) melaksanakan tugas tambahan yang melekat pada pelaksanaan kegiatan pokok sesuai dengan beban kerja guru. Oleh karena itu dalam pelaksanaannya, supervisi harus dilakukan secara teratur dan berkesinambungan sehingga kualitas pembelajaran dapat meningkat.

Berkaitan dengan ruang lingkup supervisi akademik, Permendiknas no. 39 tahun 2009 menyebutkan bahwa ruang lingkup supervisi akademik meliputi: 1) membina guru dalam merencanakan, melaksanakan dan menilai proses pembelajaran, 2) memantau pelaksanaan standar isi, 3) memantau pelaksanaan standar proses, 4) memantau pelaksanaan standar kompetensi kelulusan, 5) memantau pelaksanaan standar tenaga pendidik dan 6) memantau pelaksanaan standar penilaian.

Berkaitan dengan tujuan supervisi, tujuan umum supervisi pendidikan adalah memperbaiki situasi belajar mengajar, baik belajar para peserta didik, maupun situasi mengajar guru. Piet A. Sahertian (2010: 19) berpendapat bahwa tujuan supervisi pendidikan adalah memberikan layanan untuk mengembangkan situasi belajar mengajar yang dilakukan guru di kelas. Dengan demikian, tujuan supervisi adalah memberikan layanan dan bantuan untuk meningkatkan kualitas mengajar guru di kelas sehingga kualitas belajar siswa dapat meningkat. Adapun menurut Wiles dan W.H. Burton sebagaimana dikutip oleh Burhanuddin (2002), tujuan supervisi pendidikan adalah untuk membantu mengembangkan situasi belajar mengajar ke arah yang lebih baik melalui pembinaan dan peningkatan profesi 
mengajar. Secara lebih rinci dapat dijelaskan sebagai berikut: 1) Meningkatkan efektivitas dan efisiensi belajar mengajar,2) Mengendalikan penyelenggaraan bidang teknis edukatif di sekolah sesuai dengan ketentuan-ketentuan dan kebijakan yang telah ditetapkan,3) Menjamin agar kegiatan sekolah berlangsung sesuai dengan ketentuan yang berlaku, sehingga berjalan lancar dan memperoleh hasil optimal,4) Menilai keberhasilan sekolah dalam pelaksanaan tugasnya,5) Memberikan bimbingan langsung untuk memperbaiki kesalahan, kekurangan, dan kesulitan yang dihadapi serta membantu memecahkan masalah yang dihadapi sekolah sehingga dapat dicegah kesalahan yang lebih jauh.

Tujuan supervisi tidak hanya memperbaiki mutu mengajar guru, tetapi juga membina pertumbuhan profesi guru dalam arti luas termasuk pengadaan fasilitas yang menunjang kelancaran pembelajaran, serta meningkatkan kualitas guru dalam hal pengetahuan, ketrampilan, evaluasi pengajaran, pemilihan dan penggunaan metode mengajar.

\section{Fungsi Supervisi}

Menurut W.H. Burton dan Leo. J. Bruckner (1955: 3) sebagaimana dikutip oleh Piet A.Sahertian (2010: 21) fungsi utama supervisi adalah menilai dan memperbaiki faktor-faktor yang mempengaruhi proses pembelajaran.

Menurut Swearingen dalam Piet A Sahertian (2010: 21), terdapat 8 hal yang menjadi fungsi supervisi yakni sebagai berikut:1) Mengkoordinasikan semua usaha sekolah,2) Memperlengkapi kepemimpinan sekolah,3) Memperluas pengalaman guru-guru,4) Menstimulasi usaha-usaha yang kreatif,5) Memberi fasilitas dan penilaian yang terus menerus,6) Menganalisis situasi belajar mengajar,7) Memberikan pengetahuan dan keterampilan kepada setiap anggota staf, dan 8) Mengintegrasikan tujuan pendidikan dan membantu meningkatkan mengajar guruguru.

Sesuai dengan fungsinya, supervisi harus bisa mengkoordinasikan semua usaha-usaha yang ada di lingkungan sekolah yang bisa mencakup usaha setiap guru dalam mengaktualisasikan diri dan ikut memperbaiki kegiatan-kegiatan sekolah. Dengan demikian perlu dikoordinasikan secara terarah agar benar-benar dapat mendukung kelancaran program secara keseluruhan. Supervisi ditujukan untuk menghasilkan perubahan manusia kearah yang dikehendaki, kemudian kegiatan supervisi harus disusun dalam suatu program yang merupakan kesatuan yang direncanakan dengan teliti dan ditujukan kepada perbaikan pembelajaran. Supervisi pendidikan menghendaki agar proses pendidikan dapat berjalan lebih baik efektif dan optimal yaitu lebih mempercepat tercapainya tujuan, lebih memantapkan penguasaan materi, lebih menarik minat belajar peserta didik, lebih baik daya serapnya, lebih banyak jumlah peserta didik yang mencapai ketuntasan belajar, 
Supervisi Akademik untuk Meningkatkan Kompetensi Guru di SD Laboratorium UKSW (Suhandi Astuti)

lebih mantap pengelolaan administrasinya, lebih mantap pemanfaatan media belajarnya.

Menurut Suharsimi (2004: 13) supervisi memiliki tiga fungsi yaitu fungsi meningkatkan mutu pembelajaran, fungsi memicu unsur yang terkait dengan pembelajaran, fungsi membina dan memimpin. Fungsi supervisi dalam bidang evaluasi menurut Ngalim Purwanto (2014: 87) adalah menguasai dan memahami tujuan pendidikan dan menyimpulkan hasil-hasil penilaian untuk mendapat gambaran tentang kemungkinan-kemungkinan dalam mengadakan perbaikan.

Berdasarkan beberapa pendapat di atas, penulis dapat menyimpulkan bahwa inti dari fungsi supervisi pendidikan ditujukan untuk perbaikan dan peningkatan proses pembelajaran yang membantu tugas guru dalam mengajar untuk mencapai keprofesionalitasan guru dalam menunjang tujuan pembelajaran dan tujuan pendidikan yang efektif.

Menurut Bambang (2008), langkah-langkah kepala sekolah dalam melakukan supervisi pendidikan di sekolah dasar adalah sebagai berikut:1) Tahap persiapan, meliputi menyiapkan instrumen, jadwal,2) Tahap pelaksanaan, meliputi pelaksanaan observasi dari kepala sekolah, 3) Tahap pelaporan, meliputi mengidentifikasi hasil pengamatan pada saat observasi di kelas, menganalisis hasil supervisi, mengevaluasi bersama antara kepala sekolah dan guru, membuat catatan hasil supervisi yang didokumentasikan sebagai laporan,4) Tahap tindak lanjut, meliputi mendiskusikan dan membuat solusi bersama, memberitahukan hasil pelaksanaan kunjungan kelas, mengkomunikasikan kepada guru.

Berdasarkan pendapat di atas, prosedur pelaksanaan supervisi meliputi tahapan perencanaan, pelaksanaan, evaluasi, dan tindak lanjut supervisi.

\section{Kompetensi Guru dalam melakukan Penilaian}

Menurut Muhaimin (2004: 151) kompetensi adalah seperangkat tindakan intelegen penuh tanggung jawab yang harus dimiliki seseorang sebagai syarat untuk dianggap mampu melaksankan tugas-tugas dalam bidang pekerjaan tertentu. McAhsan (1981:45), dalam Mulyasa (2003:38) mengemukakan bahwa kompetensi: “...is a knowledge, skills, and abilities or capabilities that a person achieves, which become part of his or her being to the extent he or she can satisfactorily perform particular cognitive, affective, and psychomotor behaviors". Dalam hal ini, kompetensi diartikan sebagai pengetahuan, keterampilan, dan kemampuan yang dikuasai oleh seseorang yang telah menjadi bagian dari dirinya, sehingga ia dapat melakukan perilaku-perilaku kognitif, afektif, dan psikomotorik dengan sebaik-baiknya. Sedangkan menurut Syah (2000:230), "kompetensi" adalah kemampuan, kecakapan, keadaan berwenang, atau memenuhi syarat menurut ketentuan hukum. 
Selanjutnya masih menurut Syah, dikemukakan bahwa kompetensi guru adalah kemampuan seorang guru dalam melaksanakan kewajiban-kewajibannya secara bertanggung jawab dan layak. Jadi kompetensi profesional guru dapat diartikan sebagai kemampuan dan kewenangan guru dalam menjalankan profesi keguruannya. Guru yang kompeten dan profesional adalah guru piawi dalam melaksanakan profesinya.Berdasarkan uraian di atas kompetensi guru dapat didefinisikan sebagai penguasaan terhadap pengetahuan, keterampilan, nilai dan sikap yang direfleksikan dalam kebiasaan berpikir dan bertindak dalam menjalankan profesi sebagai guru.

Menurut Undang-undang No.14 tahun 2005 tentang Guru Dan DosenPasal 10 ayat (1) kompetensi guru meliputikompetensi: 1) kompetensi pedagogik, 2) kompetensi kepribadian, 3) kompetensisosial, dan 4) kompetensi profesional.

Kompetensi Pedagogik Guru SD/MI berdasarkan Permen No. 16 Tahun 2007 meliputi : 1) menguasai karakteristik peserta didik dari aspek fisik, moral, sosial, kultural, emosional, dan intelektual, 2) menguasai teori belajar dan prinsipprinsip pembelajaran yang mendidik, 3) mengembangkan kurikulum yang terkait dengan mata pelajaran/bidang pengembangan yang diampu, 4) menyelenggarakan pembelajaran yang mendidik, 5) memanfaatkan teknologi informasi dan komunikasi untuk kepentingan pembelajaran, 6) memfasilitasi pengembangan potensi peserta didik untuk mengaktualisasikan berbagai potensi yang dimiliki, 7) Berkomunikasi secara efektif, empatik, dan santun dengan peserta didik, 8) menyelenggarakan penilaian dan evaluasi proses dan hasil belajar, 9) memanfaatkan hasil penilaian dan evaluasi untuk kepentingan pembelajaran, dan 10) melakukan tindakan reflektif untuk peningkatan kualitas pembelajaran.

Selanjutnya dalam Permendiknas No. 16 Tahun2007 menyebutkan kompetensi guru SD/MI antara lain: 1) memahami prinsip-prinsip penilaian dan evaluasi proses dan hasil belajar sesuai dengan karakteristik lima mata pelajaran $\mathrm{SD} / \mathrm{MI}$; 2)menentukan aspek-aspek proses dan hasil belajar yang penting untuk dinilai dan dievaluasi sesuai dengan karakteristik lima mata pelajaran SD/MI; 3) menentukan prosedur penilaian dan evaluasi proses dan hasil belajar; 4) mengembangkan instrumen penilaian dan evaluasi proses dan hasil belajar; 5) mengadministrasikan penilaian proses dan hasil belajar secara berkesinambungan dengan mengunakan berbagai instrumen;6) menganalisis hasil penilaian proses dan hasil belajar untuk berbagai tujuan; 7) melakukan evaluasi proses dan hasil belajar.

Berkaitan dengan kompetensi penilaian belajar, Depdiknas (2004:9) mengemukakan kompetensi penilaian belajar peserta didik, meliputi 1) mampu memilih soal berdasarkan tingkat kesukaran,2) mampu memilih soal berdasarkan tingkat pembeda, 3) mampu memperbaiki soal yang tidak valid, 4) mampu memeriksa jawab, 5) mampu mengklasifikasi hasil-hasil penilaian, (6) mampu mengolah dan menganalisis hasil penilaian, 7) mampu membuat interpretasi 
Supervisi Akademik untuk Meningkatkan Kompetensi Guru di SD Laboratorium UKSW (Suhandi Astuti)

kecenderungan hasil penilaian, 8) mampu menentukan korelasi soal berdasarkan hasil penilaian, 9) mampu mengidentifikasi tingkat variasi hasil penilaian, (10) mampu menyimpulkan dari hasil penilaian secara jelas dan logis, 11) mampu menyusun program tindak lanjut hasil penilaian, 12) mengklasifikasi kemampuan siswa, 13) mampu mengidentifikasi kebutuhan tindak lanjut hasil penilaian, 14) mampu melaksanakan tindak lanjut, 15) mampu mengevaluasi hasil tindak lanjut, dan 16) mampu menganalisis hasil evaluasi program tindak lanjut hasil penilaian. Berdasarkan uraian di atas kompetensi pedagogik tercermin dari indikator 1) kemampuan merencanakan program belajar mengajar, 2) kemampuan melaksanakan interaksi atau mengelola proses belajar mengajar, dan 3) kemampuan melakukan penilaian.

\section{METODE}

Jenis penelitian yamng diterapkan dalam penelitian ini merupakan penelitian tindakan sekolah menggunakan model supervisi. Dilaksanakan di SD Laboratorium UKSW Salatiga. Pelaksanaan penelitian ini dilakukan melalui tahap studi pendahuluan, penyusunan proposal penelitian, penyusunan instrumen, pengumpulan data, analisis data, pembahasan hasil analisis data, dan penyusunan laporan. Subyek yang dilibatkan dalam penelitian adalah 15 orang guru, dengan mengukur skor kemampuan guru menyusun dan mengadministrasikan penilaian pembelajaran. Penelitian tindakan sekolah ini dilakukan menggunakan model supervisi

\section{HASIL DAN PEMBAHASAN}

Dalam upaya meningkatkan kualitas sumber daya guru SD Laboratorium UKSW kepala sekolah melakukan: 1) pembinaan guru dalam merencanakan, melaksanakan dan menilaia proses pembelajaran, 2) Pemantauan pelaksanaan standar isi, 3) pemantauan pelaksanaan standar proses, 4) pemantauan pelaksanaan standar kompetensi kelulusan, 5) pemantauan pelaksanaan standar tenaga pendidik dan 6) pemantauan pelaksanaan standar penilaian.

Peningkatkan sumber daya guru yang berkualitas perlu dilakukan secara terprogram, terstruktur dan berkelanjutan melalui pembinaan profesional yang dilakukan oleh kepala sekolah selaku manajer sumber daya manusia. Melalui supervisi akademik kepala sekolah mampu menampung berbagai masalah yang dihadapi oleh guru dalam proses pembelajaran untuk dapat menemukan cara-cara pemecahan permasalahan. Esensi supervisi akademik adalah membantu guru mengembangkan kemampuan profesionalismenya. Hal ini juga dilakukan oleh kepala sekolah SD Laboratorium UKSW dalam pemecahan masalah yang berkaitan dengan administrasi penilaian pembelajaran dimana ada sebagian guru di SD Laboratorium UKSW yang belum kompeten dalam menyusun administrasi 
penilaian pembelajaran dengan baik. Dengan melakukan Supervisi Akademik tingkat kompetensi penyusunan administrasi penilaian pembelajaran di SD Laboratorium menghasilkan peningkatan 26,2 \% dari kondisi awal skor 63,5 setelah dilakukan supervisi menjadi 89,6 ( Suhandi Astuti,2015: 125).

Langkah konkrit yang dilakukan oleh kepala sekolah SD Laboratorium UKSW sebagai supervisor dengan melakukan observasi langsung yang bertujuan untuk memperoleh data secara obyektif sehingga data yang diperoleh dapat digunakan untuk menganalisis kesulitan-kesulitan yang dihadapi guru.Teknik pengumpulan data menggunakan teknik obeservasi kelas.Instrumenobservasi yang digunakan adalah alat penilaian kemampuan guru (APKG) berupa: kisi-kisi instrument pengukuran.Instrument penilaian administrasi pembelajaran.Kisi-kisi instrument instrument kemampuan guru dalam melakukan penilaian administrasi pembelajaran mencakup 10 komponenyaitu: 1) Bukunilai/Daftarnilai (item no 1); 2) PelaksaanTes (kognitif): UH,UTS,UAS (item no 2); 3) Penugasanterstruktur (PT) (item no 3);4) Kegiatan mandiri tidak terstruktur (KMTT) (item no 4); 5) Pelaksanaan penilaian ketrampilan (psikomotor) (item no 5);6) Pelaksanaan penilaian Afektif akhlak mulia (item no 6); 7) Pelaksanan penilaian Afektif kepribadian (item no 7); 8) Program dan pelaksanaan Remidial (item no 8); 9) Analisis hasil ulangan(item no 9); dan 10) Bank Soal/Instrumen Tes (item no 10).

Sama seperti halnya kisi-kisi Instrument penilaian tersebutdi atas, Instrumen penilaian ini mencakup10 komponen, yaitu:1) Bukunilai/Daftarnilai; 2) PelaksaanTes (kognitif): UH,UTS,UAS;3) Penugasan terstruktur(PT);4) Kegiatan mandiri tidak terstruktur (KMTT); 5) Pelaksanaan penilaian ketrampilan (psikomotor);6) Pelaksanaan penilaian Afektif akhlak mulia;7) Pelaksanan penilaian Afektif kepribadian;8) Program dan pelaksanaan Remidial; 9) Analisis hasil ulangan; 10) Bank Soal/Instrumen Tes.

Tiap item instrument penilaian terdapat 5 kategori pensekoranya itu 1, 2, 3,4 dan 5.Setiap skor yang diperoleh kemudian dibagi dengan skor maksimal dan dikalikan dengan 100 atauN $=\frac{\text { gkoryung diperoleh }}{\text { skor maksimal }} \times 100$. Adapun kriteria penilaian yaitu: Baik Sekali berada di skor 91 sampai 100, Baik berada pada skor 76 sampai 90, Cukup berada pada skor 61 sampai 75, Kurang berada pada skor 51 sampai 60 sedangkan Kurang Sekali berada pada skor kurang dari 50.

Analisis data yang digunakan adalah teknik analisis deskriptif komparatif.Data kuantitatif yang diperoleh di deskripsikan dalambentuk kata-kata atau penjelasan.Selanjutnya akan dilakukan komparasi data untuk memastikan ada tidaknya peningkatan kemampuan guru dalam menyusun perencanaan pembelajaran, peningkatan kemampuan guru dalam pelaksanaan.

Berdasarkan wawancara dengan guru di SD Laboratorium, hasil dari proses supervisi akademik menyatakan bahwa supervisi akademik bermanfaat dalam meningkatkan kompetensi guru, caranya mudah diterima, serta saran yang diberikan oleh kepala sekolahpun mudah dilakukan.

Hasil supervisi yang dilakukan oleh kepala sekolah SD Laboratorium UKSW menunjukkan adanya peningkatan. Pada kondisi awal rata-rata tingkat kompetensi penyusunan administrasi penilaian pembelajaran 63,5 (skor ideal 100) setelah diberi tindakan rata-rata kompetensi penyusunan administrasi penilaian pembelajaran 89,6. Data 
Supervisi Akademik untuk Meningkatkan Kompetensi Guru di SD Laboratorium UKSW (Suhandi Astuti)

tersebut menunjukkan kompetensi penyusunan administrasi penilaian pembelajaran mengalami peningkatan $26,2 \%$.

Ada beberapa kendala yang dihadapi dalam melakukan supervisi akademik yang dilakukan oleh kepala sekolah diantaranya adalah sebagai berikut.: 1) Guru mempunyai pekerjaan yang padat dalam mengajar di kelas sehingga guru kurang perhatian terhadap supervisi yang dilakukan oleh kepala sekolah, 2) Waktu pelaksanaan supervisi kadang-kadang kurang dan tidak terjadwal yang disebabkan oleh kesibukan kepala sekolah, 3) Sebagian kepala sekolah merangkap tugas mengajar di kelas sehingga kepala sekolah belum melaksanakan supervisi akademik secara rutin yang mengakibatkan pelaksanaan supervisi akademik belum sepenuhnya berjalan secara baik.

Upaya yang dilakukan oleh kepala sekolah dalam menghadapi kendala yang dihadapi dalam supervisi akademik, adalah sebagai berikut: 1) Mempergunakan waktu istirahat atau waktu luang untuk membahas permasalahan yang dihadapi oleh guru, 2) Kepala sekolah melakukan pendekatan langsung secara individu kepada masing-masing guru dalam melaksanakan supervisi akademik.

\section{SIMPULAN DAN SARAN}

Supervisi akademik dapat meningkatkan kemampuan guru khususnya kemampuan dalam menyusun administrasi penilaian. Dalam rangka meningkatkan kemampuan guru diperlukan bimbingan dan pengarahan dari kepala sekolah selaku supervisor. Apabila supervisi akademik dilaksanakan secara intensif atau dilaksanakan secara berkelanjutan, maka kinerja guru dapat meningkat dan proses belajar mengajar dapat berkualitas, sehingga output sekolah juga akan berkualitas.

Berdasarkan simpulan tersebut, maka diajukan saran berikut: Kepala sekolah perlu aktif mengikuti pembimbingan teknik pelaksanaan supervisi akademik, Kepala sekolah diharapkan punya keberanian melaksanakan supervisi akademik terhadap guru-guru di sekolahnya, Kepala sekolah perlu membuat program supervisi setiap tahunnya, Untuk meningkatkan kualitas kepala sekolah kiranya dapat melaksanakan pembinaan secara berkesinambungan.

\section{DAFTAR PUSTAKA}

Bangun,Wilson.2012. Manajemen Sumber Daya Manusia. Jakarta. Erlangga.

Burhanudin. 1990. Analisis administrasi manajemen dan kepemimpinan pendidikan. Jakarta: Bumi Aksara.

Muhaimin. 2004. Paradigma Pendidikan Islam. Bandung: PT Remaja Rosdakarya. 
Scholaria, Vol. 7 No 1, Januari 2017: 49 - 59

Mulyasa, E. 2003. Kurikulum Berbasis Kompetensi: Konsep, Karakteristik, dan Implementasi. Bandung: PT Remaja Rosdakarya

Mawansyah. 2010. Manajemen Sumber Daya Manusia. Bandung: Alfabeta

Nana, Sudjana. 2011. Buku Kerja Pengawas Sekolah. Pusat Pengembangan Tenaga Kependidikan, Badan PSDM dan PMP. Jakarta: Kementerian Pendidikan dan Kebudayaan.

Peraturan Menteri Nomor 16 Tahun 2007 tentang Standar Kualifikasi Akademik dan kompetensi Guru. Jakarta: Kemendikbud.

Purwanto, Bambang. 2008. Pelaksanaan pembinaan oleh kepala sekolah dalam meningkatkan kinerja guru sekolah dasar di kecamatan purwokerto selatan kabupaten banyumas. Tesis. Yogyakarta: Perpustakaan UNY

Pujiono. 2014. Laporan Pelaksanaan Supervisi Akademik. SD Kristen Satya Wacana.

Purwanto, Ngalim. 2014. Administrasi dan supervisi pendidikan. Bandung: Remaja Rosdakarya.

Suhandi Astuti. 2016. Penerapan Supervisi Akademik untuk Meningkatkan Kompetensi Guru dalam Menyusun Administrasi Penilaian di SD Laboratorium UKSW. Scholaria 6 (1): 117-126

Suhertian,(2010).Konsep Dasar dan Teknik Supervisi Pendidikan.Jakarta: RinekaCipta

Syah, Muhibbin. 2000. Psikologi Pendidikan dengan Pendekatan Baru. Bandung: PT Remaja Rosdakarya.

2009. Undang-UndangNomor 39 tahun 2009 Tentang pemenuhan Beban Kerja Guru dan Pengawas Satuan Pendidikan. Jakarta.

2005. Undang-Undang RI No. 14 Th. 2005 Tentang Guru dan Dosen. Jakarta:Depdiknas. 